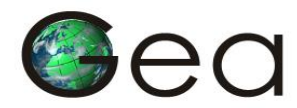

JURNAL PENDIDIKAN GEOGRAFI

\title{
PENGARUH PEMBELAJARAN KONTEKSTUAL TERHADAP HASIL BELAJAR (STUDI EKSPERIMEN PADA MATA PELAJARAN GEOGRAFI KELAS VII DI SMPN 4 PADALARANG)
}

\author{
Hilman Latief ${ }^{1}$, Dede Rohmat ${ }^{2}$, Epon Ningrum ${ }^{3}$ \\ ${ }^{1}$ Mahasiswa Prodi Pendidikan Geografi, SPs, UPI, email: \\ ${ }^{2}$ Jurusan Pendidikan Geografi, FPIPS UPI, email: rohmat_dede@yahoo.com \\ 3Jurusan Pendidikan Geografi, FPIPS, UPI, email: epon.ningrum@yahoo.com
}

\begin{abstract}
Learning is an activity that can result in changes in a person, both actual and potential. Learning will be more meaningful if the child has learned what not to know. One of the methods that position the active role of students in this study is a method of contextual learning. Issues raised in this study is whether there are differences in initial test scores and final scores as well as differences in learning outcomes in the experimental class using contextual learning and classroom control using conventional methods. The design used in this study is a quasi experimental, Nonequivalent (Pretest and posttest) Control-Group Design on class VII SMP 4 Padalarang. The independent variables are contextual learning. The dependent variable is the student learning outcomes. Testing the difference of the average pretest and posttest score results using the $t$ test at significance level $\alpha=0.05$, with a basis for decision making Ho is accepted if $\mathrm{t}\langle\mathrm{t}$ table, otherwise the Ho is rejected if $\mathrm{t}$ count $>\mathrm{t}$ table. The result of the calculation is the average difference using t-test at $\alpha=0.05$, df 39 is obtained $t=6.773$, whereas the $t$ table $=11.099$. Because it uses a two-sided test, the acceptance region is a table- $\mathrm{t} \leq \mathrm{t} \leq \mathrm{t}$ table. Meanwhile $\mathrm{t}(6.773)<\mathrm{t}$ table (1.690), therefore the Ho $=$ accepted. From the calculation of Ngain per class research $12.5 \%$ of students were high, $72.5 \%$ medium category and $15 \%$ lower category. From these calculations it can be concluded occur influence learning outcomes were greater in the experimental class than the control class. The conclusion of this study that there is a significant effect of contextual learning on learning outcomes as indicated by the change in the value of better learning outcomes than the value of the results of the previous study on class VII SMP 4 Padalarang
\end{abstract}

Keywords: Contextual Teaching and Learning, Learning Outcomes, Pretest, Posttest, $N$ Gain.

\begin{abstract}
ABSTRAK
Belajar adalah aktivitas yang dapat menghasilkan perubahan dalam diri seseorang, baik secara aktual maupun potensial. Belajar akan lebih bermakna jika anak mengalami apa yang dipelajarinya, bukan mengetahuinya. Salah satu metode pembelajaran yang memposisikan peran aktif siswa dalam pembelajaran ini adalah metode pembelajaran kontekstual. Masalah yang diangkat dalam penelitian ini adalah apakah terdapat perbedaan nilai tes awal dan nilai tes akhir serta perbedaan hasil belajar pada kelas eksperimen yang menggunakan metode pembelajaran kontekstual dan kelas kontrol yang menggunakan metode konvensional. Desain yang digunakan dalam penelitian ini adalah kuasi eksperimen Nonequivalent (pretest and posttest) Control-Group Design pada siswa kelas VII SMPN 4 Padalarang. Variabel bebas
\end{abstract}


adalah pembelajaran kontekstual. Sedangkan variabel terikat adalah hasil belajar siswa. Pengujian perbedaan nilai pretest dan rata-rata nilai hasil posttest dengan menggunakan uji $t$ pada taraf signifikansi $\alpha=0,05$, dengan dasar pengambilan keputusan Ho diterima jika thitung $<t$ tabel, sebaliknya Ho ditolak jika $t$ hitung $>t$ tabel. Hasil yang didapat dari perhitungan perbedaan rata-rata menggunakan uji $t$ pada $\alpha=0,05$, df 39 diperoleh $t$ hitung $=6,773$, sedangkan $t$ tabel $=11,090$. Karena menggunakan uji dua sisi, maka daerah penerimaannya adalah $-t$ tabel $\leq t$ hitung $\leq t$ tabel. Sementara itu $t$ hitung $(6,773)<t$ tabel $(1,690)$, oleh karena itu maka $\mathrm{Ho}=$ diterima. Dari hasil perhitungan $\mathrm{N}$-gain tiap kelas penelitian sebanyak $12,5 \%$ peserta didik termasuk kategori tinggi, 72,5\% kategori sedang dan 15\% kategori rendah. Dari perhitungan tersebut dapat disimpulkan terjadi pengaruh hasil belajar yang lebih besar pada kelas eksperimen daripada kelas kontrol. Kesimpulan dari penelitian ini terdapat pengaruh yang signifikan dari pembelajaran kontekstual terhadap hasil belajar yang ditunjukkan dengan adanya perubahan nilai hasil belajar yang lebih baik dari nilai hasil belajar sebelumnya pada siswa kelas VII SMPN 4 Padalarang.

Kata Kunci: Pembelajaran Kontekstual, Hasil Belajar, Pretest, Posttest, N-Gain

\section{PENDAHULUAN}

\section{a. Latar Belakang}

Salah satu permasalahan pendidikan yang dihadapi oleh pemerintah dan bangsa Indonesia saat ini adalah masih rendahnya mutu pendidikan, khususnya pada jenjang pendidikan dasar dan menengah. Berbagai upaya telah dilakukan oleh pemerintah untuk meningkatkan mutu pendidikan nasional, melalui penyempurnaan sistem pendidikan. Namun demikian, sampai saat ini berbagai indikator peningkatan mutu pendidikan belum menunjukkan peningkatan yang memadai dan merata diantaranya: (1) keluaran/lulusan sekolah yang relevan dengan kebutuhan masyarakat, dan (2) penampilan kemampuan dalam semua komponen pendidikan. Peningkatan mutu pendidikan masih lebih banyak memandang segi kuantitas (output).

Dalam Proses pembelajaran Geografi (IPS), seorang guru memiliki peran penting dalam menyampaikan informasi, melatih keterampilan dan membimbing belajar siswa sehingga para guru dituntut memiliki kualifikasi dan kompetensi tertentu, agar proses belajar dan pembelajaran dapat berlangsung efektif dan efisien. Hal yang menjadi hambatan selama ini dalam pembelajaran Geografi adalah disebabkan kurang dikemasnya pembelajaran Geografi dengan metode yang menarik, menantang, dan menyenangkan. Para guru seringkali menyampaikan materi Geografi dengan cara konvensional, sehingga pembelajaran Geografi cenderung membosankan dan kurang menarik minat siswa, yang pada gilirannya prestasi belajar siswa kurang memuaskan.

Pendekatan dan Model Pembelajaran sebagai salah satu komponen pembelajaran memiliki peranan dalam upaya pencapaian tujuan pembelajaran. Pendekatan pembelajaran kontekstual merupakan salah satu pendekatan pembelajaran yang digunakan dalam pembelajaran Geografi (IPS). Penggunaan pendekatan kontekstual diharapkan dapat membantu dalam proses pencapaian kompetensi siswa yang bersifat pemahaman terhadap lingkungan kehidupan manusia. Dalam pendekatan pembelajaran kontekstual tidak hanya mencakup aspek kognitif saja tetapi mencakup seluruh aspek hasil belajar yaitu, kognitif, afektif dan psikomotor dan membuat pembelajaran lebih bermakna dengan menghubungkan materi pembelajaran dengan kehidupan sehari-hari siswa.

Berdasarkan pengamatan peneliti selama bertugas di SMP Negeri 4 Padalarang masih banyak guru yang menggunakan pendekatan pembelajaran konvensional, penyampaian materi hanya dengan ceramah dan partisipasi siswa dalam pembelajaran sangat kurang sehingga siswa 
cenderung pasif, begitu juga dalam pembelajaran Geografi (IPS) guru hanya menggunakan pendekatan pembelajaran konvensional dan siswa kurang aktif dalam proses pembelajaran sehingga materi yang disampaikan kurang bisa dipahami oleh siswa. Tidak adanya kesempatan siswa untuk membangun dan mengembangkan pengetahuannya karena penggunaan pendekatan pembelajaran yang kurang inovatif menjadikan siswa kurang paham terhadap hasil belajar yang harus mereka capai.

Dari beberapa penelitian pendekatan pembelajaran kontekstual yang pernah dilakukan sebagian besar peneliti hanya membahas implementasi pembelajaran kontekstual dari mulai perencanaan sampai tahap pelaksanaan dan sedikit yang membahas tentang pengaruh pendekatan pembelajaran kontekstual terhadap hasil belajar. Bertolak dari pembahasan tersebut dan rekomendasi dari peneliti terdahulu tentang perlunya diadakan penelitian pengaruh pendekatan pembelajaran kontekstual maka penulis tertarik untuk meneliti lebih lanjut tentang pendekatan pembelajaran kontekstual.

\section{b. Landasan Operasional Pembelajaran Kontekstual}

Pembelajaran merupakan suatu sistem yang terdiri atas berbagai komponen yang saling berhubungan dan saling mempengaruhi. Komponen-komponen itu dapat dikelompokkan kedalam tiga kategori utama, yaitu guru, isi dan materi pembelajaran, dan siswa. Menurut Rusman (2008:243) "Pembelajaran merupakan implementasi kurikulum di sekolah dari kurikulum yang sudah dirancang dan menuntut aktivitas dan kreativitas guru dan siswa sesuai dengan rencana yang telah diprogramkan, secara efektif dan menyenangkan". Sedangkan Sumi'at (2008:3) menyatakan bahwa Pembelajaran dalam kegiatan pendidikan merupakan komponen inti dalam pendidikan formal di sekolah yang didalamnya terjadi interaksi antara berbagai komponen pembelajaran yang meliputi tujuan, materi, metode dan evaluasi.

Menurut Sukmadinata (2013:131) Pembelajaran pada dasarnya merupakan kegiatan guru/dosen menciptakan situasi agar siswa belajar. "Interaksi dalam proses belajar mengajar merupakan indikator penting dalam mengantarkan siswa memperoleh pengetahuan dan nilainilai yang diberikannya (Mahfudin, 2009:57).

Dengan demikian pembelajaran atau pengajaran adalah segenap upaya yang dilakukan untuk menciptakan situasi agar peserta didik belajar.

Pendekatan pembelajaran dapat diartikan sebagai pola umum atau gambaran menyeluruh yang berisi tentang rentetan kegiatan yang dapat dijadikan pedoman (petunjuk umum) dalam melaksanakan pembelajaran yang direncanakan untuk mencapai tujuan pembelajaran yang ditentukan. Hal ini sejalan dengan yang dikemukakan oleh Sanjaya (2007:127) bahwa “...pendekatan dapat diartikan sebagai titik tolak atau sudut pandang kita terhadap proses pembelajaran. Adapun menurut Rusman (2008:139), bahwa pendekatan merujuk kepada pandangan tentang terjadinya suatu proses yang sifatnya masih sangat umum.

Pendekatan pembelajaran kontekstual atau contextual teaching and learning adalah konsep belajar yang membantu guru mengaitkan antara materi yang diajarkannya dengan situasi dunia nyata siswa dan mendorong siswa membuat hubungan antara pengetahuan yang dimilikinya dengan penerapannya dalam kehidupan mereka sehari-hari, dengan melibatkan tujuh komponen utama pembelajaran efektif, yakni : pemodelan (modelling), bertanya (questioning), masyarakat belajar (learning community), menemukan (inquiry), kontruktivisme (contructivism), tindak lanjut (reflection) dan penilaian sebenarnya (authentic assessment).

Menurut hasil penelitian Romli (2010), peningkatan prestasi belajar siswa yang mendapat perlakuan pembelajaran dengan penerapan pendekatan kontekstual lebih baik daripada peningkatan prestasi belajar siswa yang mendapatkan perlakuan pembelajaran dengan pendekatan konvensional. Selain itu, siswa menunjukkan sikap yang positif terhadap mata pelajaran, pembelajaran kontekstual, dan soal-soal kontekstual yang membuat siswa merasa 
senang, tertarik, tertantang, terbantu dan dapat menumbuhkan rasa kebersamaan antara temanteman dalam kegiatan belajar kelompok.

\section{Pembelajaran Konvensional}

Menurut Zamroni, dalam Nursisto (2001: xxv) pendekatan konvensional adalah upaya peningkatan kualitas pendidikan yang bertumpu secara kaku pada paradigma input-prosesoutput. Dalam hubungannya dengan proses belajar mengajar, pendekatan pembelajaran sebagaimana yang sudah lazim digunakan dalam kegiatan pembelajaran di kelas disebut pendekatan pembelajaran konvensional.

Pendekatan konvensional merupakan pendekatan pembelajaran yang dilakukan dengan mengkombinasikan bermacam-macam metode pembelajaran. Dalam praktiknya metode ini berpusat pada guru (teacher centered) atau guru lebih mendominasi dalam kegiatan pembelajaran. Metode pembelajaran yang dilakukan berupa metode ceramah, pemberian tugas, dan tanya jawab. Pendekatan konvensional merupakan pendekatan pembelajaran yang banyak dilaksanakan di sekolah saat ini, yang menggunakan urutan kegiatan pemberian uraian, contoh, dan latihan (Wibawa dan Mukti, 1992: 5).

Dalam pembelajaran IPS Geografi di SMP pendekatan konvensional ini masih banyak digunakan untuk pembelajaran di kelas. Dasar yang digunakan untuk menentukan pilihan pendekatan konvensional ini dalam pembelajaran adalah banyaknya jumlah siswa per kelas di sekolah dan terbatasnya waktu yang tersedia untuk menyampaikan pengetahuan yang bersifat kognitif, sehingga untuk menciptakan keterampilan atau kemampuan psikomotorik siswa dilakukan dengan pemberian tugas yang dilakukan baik di dalam maupun di luar kelas. Metode pemberian tugas ini dilakukan oleh guru setelah guru menyampaikan materi pengetahuan yang bersifat kognitif dengan metode ceramah untuk memantapkan penguasaan materi dalam pembentukan kemampuan psikomotoriknya.

\section{Hasil Belajar}

Menurut Sudjana (1989: 22) hasil belajar adalah kemampuan-kemampuan yang dimiliki siswa setelah ia menerima pengalaman belajarnya. Hasil belajar yang dicapai siswa setelah melakukan kegiatan terdiri dari tiga aspek yaitu: (1) Aspek kognitif yang mencakup keterampilan-keterampilan intelektual, informasi dan pengetahuan: (2) Aspek afektif menekankan pada sikap, nilai, perasaan, dan emosi; dan (3) Aspek Psikomotor berhubungan dengan keterampilan motorik, manipulasi benda atau kegiatan yang memerlukan koordinasi syaraf.

Hasil belajar bisa didapat dari berbagai bentuk penilaian/evaluasi. Menurut Sumaatmaja (1997: 125) secara menyeluruh, bentuk evaluasi pada pengajaran Geografi meliputi bentuk tes dan nontes. Bentuk tes meliputi tes objektif, tes esai dan tes lisan. Sedangkan bentuk nontes berupa laporan tugas dan penampilan (presentasi).

Data yang dikumpulkan dari hasil belajar adalah nilai yang diperoleh peserta didik dari hasil pre-tes dan juga nilai yang diperoleh dari pos-tes, baik pada kelas eksperimen maupun pada kelas kontrol.

Berdasarkan pemaparan di atas, dalam penelitian ini hasil belajar diperoleh dari nilai tes, nilai tugas kelompok dan nilai presentasi kelompok.

\section{c. Rumusan Masalah}

Perumusan masalah dalam penelitian ini dimaksudkan untuk lebih memperjelas permasalahan yang akan diteliti sehingga terhindar dari kekaburan dan ketidakefektifan kerja dalam penelitian ini. Adapun yang menjadi rumusan masalah dalam penelitian ini adalah sebagai berikut: 
a. Apakah terdapat perbedaan nilai tes awal dengan tes akhir pada kelas eksperimen dengan pembelajaran kontekstual mata pelajaran Geografi (IPS) siswa di SMP Negeri 4 Padalarang?

b. Apakah terdapat perbedaan nilai tes awal dengan tes akhir pada kelas kontrol dengan pembelajaran konvensional mata pelajaran Geografi (IPS) siswa di SMP Negeri 4 Padalarang?

c. Apakah terdapat perbedaan hasil belajar Geografi (IPS) antara pembelajaran kontekstual dengan pembelajaran konvensional pada siswa di SMP Negeri 4 Padalarang?

\section{d. Tujuan Penelitian}

Sesuai dengan rumusan masalah yang telah diuraikan di atas, maka tujuan penelitian ini adalah untuk mengetahui :

a. Perbedaan nilai tes awal dengan tes akhir pada kelas eksperimen pembelajaran kontekstual mata pelajaran Geografi (IPS) siswa di SMP Negeri 4 Padalarang.

b. Perbedaan nilai tes awal dengan tes akhir pada kelas kontrol pembelajaran konvensional mata pelajaran Geografi (IPS) siswa di SMP Negeri 4 Padalarang.

c. Perbedaan hasil belajar Geografi (IPS) antara pembelajaran kontekstual dengan pembelajaran konvensional pada siswa di SMPN 4 Padalarang.

\section{METODOLOGI PENELITIAN}

\section{a. Metode dan Teknik Penelitian}

Penelitian ini adalah kuasi eksperimen, dengan dua variabel yaitu variabel bebas (independent variable) dan variabel terikat (dependent variable). Variabel bebas dalam penelitian ini adalah pembelajaran geografi baik dengan pendekatan Contextual Teaching and Learning (CTL), maupun dengan menggunakan pendekatan konvensional. Sedangkan variabel terikat adalah hasil belajar siswa yang mencakup penguasaan konsep. Jenis desain kuasi eksperimen (Quasi Experimental Design) yang peneliti gunakan dalam kajian ini, adalah desain Nonequivalent (Pre test and post test) Control-Group Design. Desain penelitian dapat dijelaskan pada Tabel 3.1 berikut.

Tabel 3.1 Desain Eksperimen

\begin{tabular}{|l|c|c|c|}
\hline \multicolumn{1}{|c|}{ Kelas } & Pretest & Perlakuan & Posttest \\
\hline Eksperimen & $\mathrm{O}_{1}$ & $\mathrm{X}$ & $\mathrm{O}_{3}$ \\
\hline Kontrol & $\mathrm{O}_{2}$ & & $\mathrm{O}_{4}$ \\
\hline
\end{tabular}

Sumber: Sukmadinata (2006: 207).

\section{Keterangan :}

$\mathrm{O}_{1}=$ Tes awal sebelum perlakuan diberikan pada kelas eksperimen

$\mathrm{O}_{2}=$ Tes awal pada kelas kontrol

$\mathrm{O}_{3}=$ Tes akhir setelah perlakuan pada kelas eksperimen

$\mathrm{O}_{4}=$ Tes akhir setelah pembelajaran pada kelas kontrol

$\mathrm{X}=$ Penerapan model pembelajaran Kontekstual

\section{b. Populasi dan Sampel}

Populasi dalam penelitian ini adalah kelas VII di SMP Negeri 4 Padalarang semester genap tahun pelajaran 2012/2013 yang berjumlah 6 kelas. 
Tabel. 3.2 Populasi Penelitian

\begin{tabular}{|c|c|c|}
\hline No & Kelas & Jumlah Siswa \\
\hline 1 & VII.A & 39 \\
\hline 2 & VII.B & 39 \\
\hline 3 & VII.C & 40 \\
\hline 4 & VII.D & 39 \\
\hline 5 & VII.E & 39 \\
\hline 6 & VII.F & 40 \\
\hline
\end{tabular}

Sampel digunakan dalam penelitian untuk mempermudah pengambilan data dari populasi. Cara penarikan sampel dalam penelitian ini adalah cara peluang atau probability sampling yaitu memberikan peluang yang sama bagi semua populasi untuk dijadikan sampel, dengan teknik penarikan sampel kelas atau cluster random sampling.

Berdasarkan penjelasan di atas, maka peneliti memilih dua kelas yang akan dijadikan sampel penelitian, dengan rincian pada tabel di bawah ini :

Tabel 3.3 Penentuan Kelas Eksperimen

\begin{tabular}{|l|l|c|c|c|c|c|c|}
\hline \multirow{2}{*}{ No } & \multirow{2}{*}{ Karakteristik } & \multicolumn{7}{|c|}{ Kelas VII } \\
\cline { 3 - 8 } & & A & B & C & D & E & F \\
\hline 1 & Nilai tertinggi & 87 & 80 & 80 & 80 & 80 & 80 \\
\hline 2 & Nilai terendah & 70 & 70 & 70 & 70 & 70 & 70 \\
\hline 3 & Nilai rata-rata & 73,18 & 73,23 & $\mathbf{7 3 , 7 1}$ & 73,27 & 74,28 & $\mathbf{7 3 , 6 8}$ \\
\hline 4 & KKM & \multicolumn{7}{|c|}{68} \\
\hline
\end{tabular}

Sumber: Nilai Raport Sem. 1 TP. 2012/2013.

Sampel yang telah ditentukan harus memiliki sifat dan karakteristik yang sama, seperti dalam hal kemampuan awal siswa sebelum diberi perlakuan. Untuk melihat kemampuan awal siswa sebelum diberi perlakuan peneliti menggunakan nilai IPS pada raport semester ganjil. Kedua kelas tersebut memiliki rata-rata nilai IPS yaitu, kelas VII.C $=73,71$ dan Kelas VII.F $=$ 73,68. Kedua rata-rata nilai tersebut tidak jauh berbeda sehingga kemampuan awal kedua kelas tersebut dianggap sama.

\section{c. Variabel Penelitian}

Variabel penelitian adalah konsep yang mempunyai nilai untuk mendefinisikan suatu kajian penelitian. Variabel penelitian ini adalah model pembelajaran Kontekstual sebagai variabel bebas dan Hasil Belajar sebagai variabel terikat, dapat dilihat pada gambar di bawah ini. 


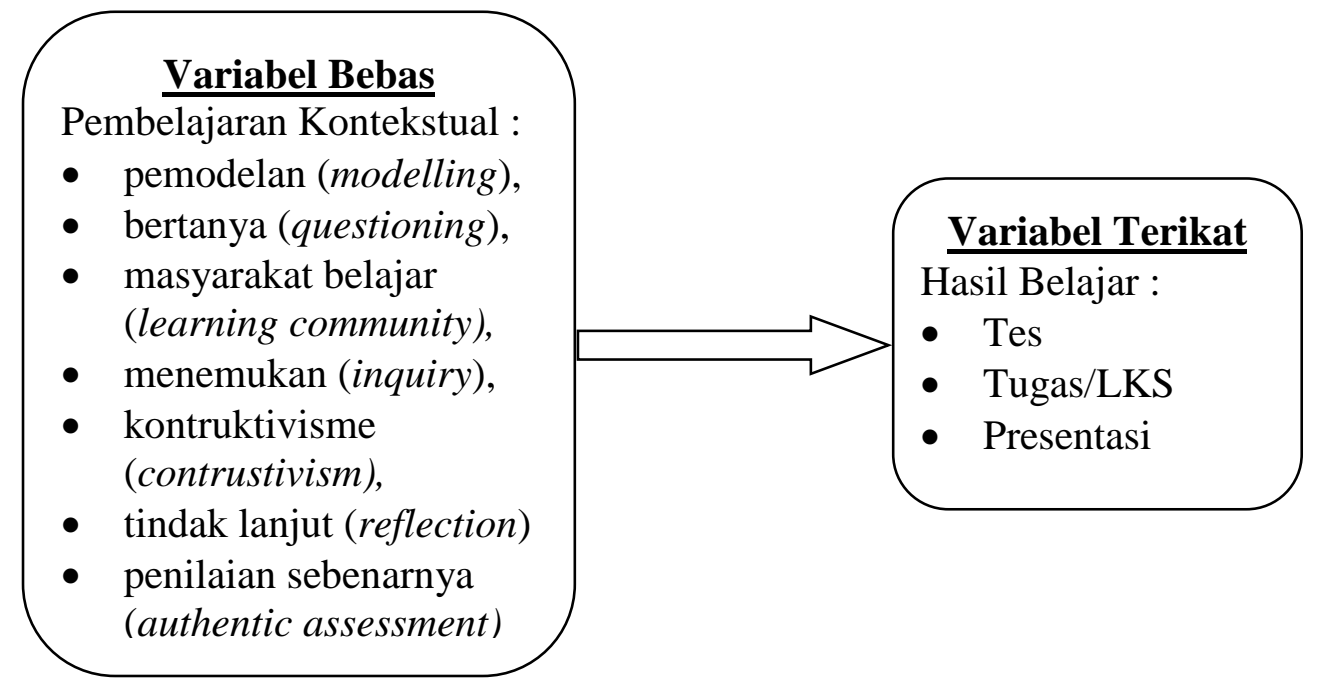

Gambar. 3.1 Hubungan antar variabel

\section{d. Instrumen Penelitian} (LKS).

Instrumen yang digunakan dalam penelitian ini terdiri dari Tes dan Lembar Kerja Siswa

\section{e. Teknik Pengolahan dan Analisis Data}

Data dalam penelitian ini dikumpulkan melalui tes pemahaman konsep melalui tes tertulis (pretest dan posttest). Data hasil penelitian diolah dan dianalisis dengan software Microsoft Excel 2007 dan software SPSS Versi 17.0 for Windows untuk menjawab rumusan masalah penelitian. Data yang diperoleh berupa hasil jawaban peserta didik terhadap tes.

\section{HASIL DAN PEMBAHASAN}

\section{a. Deskripsi Data Penelitian}

\section{Hasil Pre test dan Post test Pada Kelas Eksperimen}

Hasil pre test dan post test pada kelas eksperimen yang menggunakan model pembelajaran kontekstual dapat dilihat pada tabel 4.2 berikut.

Tabel 4.2 Hasil Skor Pre Tes, Post Tes, dan N-gain Kelas Eksperimen

\begin{tabular}{|l|r|r|r|}
\hline Nilai rata-rata & 49.25 & 75.25 & 0.48 \\
\hline Nilai Maksimal & 80 & 90 & 0.83 \\
\hline Nilai Minimal & 20 & 60 & 0.00 \\
\hline Standar Deviasi & 14.0306 & 7.84056 & 0.25126 \\
\hline Varians & 196.859 & 61.4744 & 0.06313 \\
\hline
\end{tabular}

Sumber: Hasil Penelitian 2013

Berdasarkan Tabel 4.2 di atas perolehan nilai pre test peserta didik dengan rentang nilai pada kelas eksperimen yang tertinggi 80 dan terendah 20, sehingga perolehan hasil pre test masih banyak yang di bawah KKM 70. Sedangkan apabila melihat hasil post test peserta didik dengan rentang nilai pada kelas eksperimen yang tertinggi 90 dan terendah 60, menunjukkan perbedaan nilai yang cukup signifikan dengan terlihatnya jumlah peserta didik yang dapat mencapai KKM. 


\section{Hasil Pre test dan Post Tes Pada Kelas Kontrol}

Hasil pre test dan post test pada kelas kontrol yang menggunakan model pembelajaran konvensional dapat dilihat pada tabel 4.3 berikut.

Tabel 4.3 Hasil Skor Pre Tes, Post Tes, dan N-gain Kelas Kontrol

\section{Sumber: Hasil Penelitian 2013}

\begin{tabular}{|l|r|r|r|}
\hline Nilai rata-rata & 47.5 & 62.25 & 0.28 \\
\hline Nilai Maksimal & 70 & 80 & 0.78 \\
\hline Nilai Minimal & 10 & 30 & 0.00 \\
\hline Standar Deviasi & 13.3493 & 14.2302 & 0.20453 \\
\hline Varians & 178.205 & 202.5 & 0.04183 \\
\hline
\end{tabular}

Berdasarkan Tabel 4.3 di atas perolehan nilai pre test peserta didik dengan rentang nilai pada kelas kontrol yang tertinggi 70 dan terendah 10, sehingga perolehan hasil pre test masih banyak yang di bawah KKM 70. Begitu juga apabila melihat hasil post test peserta didik dengan rentang nilai pada kelas eksperimen yang tertinggi 80 dan terendah 30, menunjukkan perbedaan nilai tetapi tidak terlalu signifikan. Masih banyak peserta didik yang mendapatkan nilai dibawah KKM yang sudah ditentukan yaitu 70 .

\section{Hasil Belajar Pada Kelas Eksperimen dan Kelas Kontrol}

Hasil belajar adalah kemampuan-kemampuan yang dimiliki siswa setelah ia menerima pengalaman belajarnya (Sudjana, 1989:22). Hasil belajar merupakan perubahan tingkah laku sebagai akibat dari proses belajar yang bersifat relatif menetap dan sesuai dengan tujuan yang telah ditentukan.

Dalam penelitian ini hasil belajar diperoleh dari nilai tes, nilai tugas dan nilai presentasi. Adapun nilai hasil belajar pada kelas eksperimen dan Kelas Kontrol dapat kita lihat pada tabel 4.4 dibawah ini.

Tabel 4.4 Rata-Rata Nilai Hasil Belajar Kelas Eksperimen dan Kelas Kontrol

\begin{tabular}{|l|c|c|}
\hline \multirow{2}{*}{} & \multicolumn{2}{|c|}{ Rata-Rata Nilai Hasil Belajar } \\
\cline { 2 - 3 } & Kelas Kontrol & Kelas Eksperimen \\
\hline Nilai rata-rata & 67.63 & 79.34 \\
\hline Nilai Maksimal & 78 & 87 \\
\hline Nilai Minimal & 53 & 72 \\
\hline Standar Deviasi & 7.57 & 3.45 \\
\hline Varians & 57.25 & 11.90 \\
\hline
\end{tabular}

Berdasarkan Tabel 4.4 di atas perolehan nilai rata-rata hasil belajar peserta didik dengan rentang nilai pada kelas kontrol yang tertinggi 78 dan terendah 53, sehingga perolehan nilai rata-rata hasil belajar menunjukkan masih banyak peserta didik yang nilai hasil belajarnya belum memenuhi KKM yang sudah ditentukan yaitu 70. Sedangkan pada kelas eksperimen nilai rata-rata hasil belajar yang tertinggi 87 dan terendah 72 , sehingga perolehan nilai rata-rata hasil belajar menunjukkan perbedaan nilai yang cukup signifikan dengan terlihatnya peserta didik yang sudah mencapai KKM yang ditentukan yaitu 70 .

Uji Gain

Rumus Gain Ternormalisasi (normalized gain) menurut Meltzer dalam Sagita, A (2011:51) sebagai berikut. 


$$
\text { Gain Ternormalisasi }(\mathrm{g})=\frac{\text { skor post test }- \text { skor pre test }}{\text { skor ideal }- \text { skor pre test }}
$$

Kriteria gain ternormalisasi $(\mathrm{g})$

$$
\begin{array}{ll}
\mathrm{g}<0,3 & : \text { rendah } \\
0,3 \leq g \leq 0,7 & : \text { sedang } \\
0,7>g & \text { : tinggi }
\end{array}
$$

Berikut tabel 4.5 menjelaskan hasil deskripsi tentang uji gain hasil belajar pada kelompok eksperimen dan kelompok kontrol yang data lengkapnya terdapat pada tabel 4.2 dan tabel 4.3.

Tabel 4.5 Uji Gain Hasil Belajar Kelas Eksperimen dan Kelas Kontrol

\begin{tabular}{|c|c|c|c|c|}
\hline \multirow{2}{*}{ Kelompok } & \multicolumn{3}{|c|}{ Gain ternormalisasi } & \multirow{2}{*}{$\begin{array}{c}\text { Rata-rata gain } \\
\text { ternormalisasi }\end{array}$} \\
\cline { 2 - 4 } & $\begin{array}{c}<0,3 \\
\text { Rendah }\end{array}$ & $\begin{array}{c}3<\mathrm{g}<0,7 \\
\text { Sedang }\end{array}$ & $\begin{array}{c}>0,7 \\
\text { Tinggi }\end{array}$ & Ench \\
\hline Eksperimen & 6 & 29 & 5 & 0,48 \\
\hline Kontrol & 23 & 16 & 1 & 0,28 \\
\hline
\end{tabular}

Sumber: Hasil Penelitian 2013

Tabel 4.5 di atas memperlihatkan bahwa nilai gain yang ternormalisasi pada kelas eksperimen kategori rendah 6, pada kategori sedang 29 dan kategori tinggi 5, rata-rata nilai gain yang ternormalisasi 0,48 (kategori sedang). Nilai gain yang ternormalisasi pada kelas kontrol kategori rendah 23, pada kategori sedang 16 dan kategori tinggi 1, rata-rata nilai gain yang ternormalisasi 0,28 (kategori rendah).

\section{Analisis Data}

Semua data terlebih dahulu dianalisis dengan uji normalitas, dan homogenitas data sehingga dapat ditentukan teknik pengujian statistik yang dilakukan. Pengolahan semua data menggunakan bantuan Program SPSS 17.0 dan Microsoft Office Excel 2007. Berikut ini diuraikan analisis data hasil penelitian.

1) Uji Normalitas

Untuk menentukan jenis uji yang digunakan apakah parametric atau non parametric maka terlebih dahulu dilakukan uji normalitas. Uji normalitas distribusi menggunakan Test of Normality berdasarkan pada uji Kolmogorov-Smirnov untuk menganalisis jenis distribusi data skor hasil belajar pada kelas eksperimen dan kelas kontrol. Pengujian dilakukan dengan membandingkan probabilitas (sig) dengan nilai alpha $(\alpha)$.

Hasil uji normalitas skor pre test dan post test kelas eksperimen, skor pre test dan post test kelas kontrol, serta $\mathrm{N}$-gain kelas eksperimen dan kelas kontrol dapat dilihat pada tabel 4.6, 4.7, dan 4.8 berikut.

Tabel 4.6

Hasil Uji Normalitas Skor Pre test dan Post test Pada Kelas Eksperimen

\begin{tabular}{|c|l|c|c|c|}
\hline No & \multicolumn{1}{|c|}{ Data } & $\begin{array}{c}\text { Nilai Probabilitas } \\
\text { (Asymp. Sig) }\end{array}$ & $\boldsymbol{\alpha}$ & Keterangan \\
\hline 1 & Pre test Kelas Eksperimen & 0,200 & 0,05 & Data berdistribusi Normal \\
\hline 2 & Post test Kelas Eksperimen & 0,118 & 0,05 & Data berdistribusi Normal \\
\hline
\end{tabular}

Sumber: Hasil Penelitian 2013

Berdasarkan tabel 4.6 diatas, dapat dilihat hasil uji normalitas skor pre test dan post test hasil belajar erosi peserta didik pada kelas eksperimen menunjukkan Asymp. Sig lebih besar 
dari nilai alpha $(\alpha)$, sehingga dapat dikatakan distribusi data skor pre test dan post test hasil belajar erosi peserta didik pada kelas eksperimen adalah berdistribusi normal.

Tabel 4.7

Hasil Uji Normalitas Skor Pre test dan Post test Pada Kelas Kontrol

\begin{tabular}{|c|l|c|c|c|}
\hline No & \multicolumn{1}{|c|}{ Data } & $\begin{array}{c}\text { Nilai Probabilitas } \\
\text { (Asymp. Sig) }\end{array}$ & $\boldsymbol{\alpha}$ & Keterangan \\
\hline 1 & Pre test Kelas Kontrol & 0,100 & 0,05 & Data berdistribusi Normal \\
\hline 2 & Post test Kelas Kontrol & 0,068 & 0,05 & Data berdistribusi Normal \\
\hline
\end{tabular}

Sumber: Hasil Penelitian 2013

Berdasarkan tabel 4.7 diatas, hasil uji normalitas skor pre test dan post test hasil belajar peserta didik pada kelas kontrol juga menunjukkan Asymp. Sig yang lebih besar dari nilai alpha $(\alpha)$, sehingga dapat dikatakan distribusi data skor pre test dan post test hasil belajar peserta didik pada kelas kontrol adalah berdistribusi normal.

Tabel 4.8

Hasil Uji Normalitas N-gain Kelas Eksperimen dan Kelas Kontrol

\begin{tabular}{|c|l|c|c|c|}
\hline No & \multicolumn{1}{|c|}{ Data } & $\begin{array}{c}\text { Nilai Probabilitas } \\
\text { (Asymp. Sig) }\end{array}$ & $\boldsymbol{\alpha}$ & Keterangan \\
\hline 1 & N-gain Kelas Eksperimen & 0,48 & 0,05 & Data berdistribusi Normal \\
\hline 2 & N-gain Kelas Kontrol & 0,28 & 0,05 & Data berdistribusi Normal \\
\hline
\end{tabular}

Sumber: Hasil Penelitian 2013

Berdasarkan tabel 4.8 di atas, diketahui hasil uji normalitas N-gain hasil belajar peserta didik pada kelas eksperimen $(0,48)$ dan kelas kontrol $(0,28)$ menunjukkan Asymp. Sig yang lebih besar dari nilai alpha $(\alpha=0,05)$, sehingga dapat dikatakan distribusi data $\mathrm{N}$-gain kelas eksperimen dan kelas kontrol adalah berdistribusi normal.

\section{2) Uji Homogenitas}

Setelah uji normalitas dan diperoleh distribusi data yang normal selanjutnya adalah melakukan uji homogenitas. Uji homogenitas dimaksudkan untuk mengetahui distribusi data homogen atau tidak homogen. Uji homogenitas pada penelitian ini menggunakan Tes of Homogeneity of Variance berdasarkan pada uji Levene Test, karena sampel diambil dari dua kelas data. Seperti halnya pengujian normalitas, pengujian homogenitas juga dilakukan dengan membandingkan nilai probabilitas (Asymp. Sig) dengan nilai alpha $(\alpha=0,05)$.

Hasil pengujian terhadap homogenitas skor pre test-post test kelas eksperimen, skor pre test-post test kelas kontrol, serta N-gain kelas eksperimen dan kelas kontrol dapat dilihat pada tabel 4.9 berikut.

Tabel 4.9

Hasil Uji Homogenitas Pre test-Post test dan N-gain Kelas Eksperimen dan Kelas Kontrol

\begin{tabular}{|c|l|c|c|l|}
\hline No & \multicolumn{1}{|c|}{ Data } & $\begin{array}{c}\text { Nilai Probabilitas } \\
\text { (Asymp. Sig) }\end{array}$ & $\boldsymbol{\alpha}$ & \multicolumn{1}{|c|}{ Keterangan } \\
\hline 1 & Pre test Post test Kelas Eksperimen & 0,559 & 0,05 & Homogen \\
\hline 2 & Pre test Post test Kelas Kontrol & 0,235 & 0,05 & Homogen \\
\hline 3 & N-gain Kelas Eksperimen dan Kelas Kontrol & 0,920 & 0,05 & Homogen \\
\hline
\end{tabular}

Sumber: Hasil Penelitian 2013 
Berdasarkan hasil uji homogenitas terhadap skor pre test - post test hasil belajar dan Ngain pada kelas ekperimen dan kelas kontrol, diperoleh nilai Asymp. Sig yang lebih besar dari nilai alpha $(>0,05)$, dengan demikian dapat dikatakan bahwa populasi tersebut adalah homogen.

\section{3) Uji Hipotesis}

Merujuk pada hasil uji normalitas dan uji homogenitas terhadap nilai pre test, post test, dan N-gain pada kelas ekperimen dan kelas kontrol yang memenuhi syarat analisis parametrik maka langkah berikutnya adalah melakukan pengujian terhadap hipotesis yang terdapat pada bab 3 dengan Uji t.

\section{Uji Hipotesis 1}

Uji hipotesis 1 merupakan pengujian perbedaan pre test dan post test hasil belajar pada kelas eksperimen yang menggunakan model pembelajaran kontekstual. Untuk melihat taraf signifikansi dari perbedaan hasil belajar peserta didik saat pre test dan post test kelas eksperimen maka dilakukan Uji beda (uji t).

Pengujian dilakukan dengan menggunakan analisis Compare Means Paired-Sample T Test, sebab data berasal dari kelas yang sama. Ketentuan yang berlaku adalah jika Asymp. Sig $<0.05$, maka terdapat perbedaan yang nyata antara nilai Pre test dengan Post test kelas eksperimen maka Ho1 ditolak dan Ha1 diterima, begitu pula sebaliknya.

Hasil analisis uji perbedaan skor pre test dan post test hasil belajar pada kelas eksperimen diperoleh nilai probabilitas $0.000<$ nilai $\alpha 0,05$, sehingga $\mathrm{Ha}_{1}$ diterima, artinya terdapat perbedaan pre test dan post test dalam hasil belajar pada kelas eksperimen yang menggunakan model pembelajaran kontekstual. Seperti yang dapat dilihat pada tabel 4.10 berikut.

Tabel 4.10

Perbandingan Pre test dan Post test Paired Samples Test

\begin{tabular}{|c|c|c|c|c|c|c|c|c|}
\hline & \multicolumn{5}{|c|}{ Paired Differences } & \multirow[b]{3}{*}{$\mathrm{t}$} & \multirow[b]{3}{*}{ df } & \multirow{3}{*}{$\begin{array}{l}\text { Sig. } \\
(2- \\
\text { tailed) }\end{array}$} \\
\hline & \multirow[b]{2}{*}{ Mean } & \multirow{2}{*}{$\begin{array}{l}\text { Std. } \\
\text { Devia- } \\
\text { tion }\end{array}$} & \multirow{2}{*}{$\begin{array}{l}\text { Std. } \\
\text { Error } \\
\text { Mean }\end{array}$} & \multicolumn{2}{|c|}{$\begin{array}{c}95 \% \text { Confidence } \\
\text { Interval of the } \\
\text { Difference }\end{array}$} & & & \\
\hline & & & & Lower & Upper & & & \\
\hline $\begin{array}{c}\text { Pair } 1 \text { Pretest - } \\
\text { Postest }\end{array}$ & -26.000 & 14.815 & 2.342 & -30.738 & -21.262 & -11.099 & 39 & .000 \\
\hline
\end{tabular}

Hasil Perhitungan, 2013

Berdasarkan tabel 4.10 di atas diperoleh nilai probabilitas $0,000<$ nilai $\alpha 0,05$, sehingga $\mathrm{Ha}_{1}$ diterima, artinya terdapat perbedaan yang signifikan antara pre test dan post test dalam hasil belajar pada kelas eksperimen yang menggunakan model pembelajaran kontekstual. Dengan demikian dapat disimpulkan bahwa hasil belajar pada kelas eksperimen menunjukan adanya perbedaan nilai yang signifikan dari skor pre test ke skor post test.

\section{Uji Hipotesis 2}

Uji hipotesis 2 merupakan pengujian perbedaan pre test dan post test pada kelas kontrol yang menggunakan model pembelajaran konvensional. Demikian juga untuk melihat taraf signifikansi dari perbedaan hasil belajar peserta didik saat pre test dan post test kelas kontrol maka dilakukan Uji beda (uji t).

Pengujian dilakukan dengan menggunakan analisis Compare Means Paired-Sample T Test, sebab data berasal dari kelas yang sama. Ketentuan yang berlaku adalah jika Asymp. Sig 
$<0.05$, maka terdapat perbedaan yang nyata antara nilai Pre test dengan Pos ttest kelas kontrol, maka $\mathrm{Ho}_{2}$ ditolak dan $\mathrm{Ha}_{2}$ diterima, begitu pula sebaliknya.

Hasil analisis uji perbedaan skor pre tes dan post test hasil belajar pada kelas kontrol dapat dilihat pada tabel 4.11 berikut.

Tabel 4.11

Uji Beda Pre test dan Post test Paired Samples Test

\begin{tabular}{|c|c|c|c|c|c|c|c|c|}
\hline & \multicolumn{5}{|c|}{ Paired Differences } & \multirow[b]{3}{*}{$\mathrm{T}$} & \multirow[b]{3}{*}{$\mathrm{df}$} & \multirow{3}{*}{$\begin{array}{l}\text { Sig. } \\
(2- \\
\text { tailed })\end{array}$} \\
\hline & \multirow[b]{2}{*}{ Mean } & \multirow{2}{*}{$\begin{array}{c}\text { Std. } \\
\text { Devia } \\
\text { tion }\end{array}$} & \multirow{2}{*}{$\begin{array}{c}\text { Std. } \\
\text { Error } \\
\text { Mean }\end{array}$} & \multicolumn{2}{|c|}{$\begin{array}{l}\text { 95\% Confidence } \\
\text { Interval of the } \\
\text { Difference }\end{array}$} & & & \\
\hline & & & & Lower & Upper & & & \\
\hline \begin{tabular}{|ll} 
Pair & Pretest - \\
1 & Postest
\end{tabular} & -14.750 & 13.772 & 2.178 & -19.155 & -10.345 & -6.773 & 39 & .000 \\
\hline
\end{tabular}

Hasil Perhitungan, 2013

Berdasarkan tabel 4.11 di atas diperoleh nilai probabilitas $0,000<$ nilai $\alpha 0,05$, sehingga $\mathrm{Ha}_{2}$ diterima, artinya terdapat perbedaan antara pre test dan post test dalam hasil belajar pada kelas kontrol yang menggunakan model pembelajaran konvensional. Dengan demikian dapat disimpulkan bahwa hasil belajar pada kelas kontrol menunjukan adanya perbedaan dari skor pre test ke skor post test, tetapi perbedaannya tidak sebesar pada kelas eksperimen.

\section{Uji Hipotesis 3}

Uji hipotesis 3 merupakan pengujian perbedaan hasil belajar pada kelas eksperimen yang menggunakan model pembelajaran kontekstual dengan kelas kontrol yang menggunakan model pembelajaran konvensional. Pengujian ini dengan membanding nilai post test dan Ngain pada kedua kelas penelitian.

Pengujian nilai post test dilakukan untuk melihat perbedaan nilai setelah perlakuan antara kelas eksperimen dan kelas kontrol, sedangkan pengujian $\mathrm{N}$-gain dilakukan untuk melihat kualitas nilai dari perbedaan pada kedua kelas penelitian tersebut. Uji hipotesis dimaksudkan untuk menentukan apakah perbedaan tersebut signifikan atau tidak.

Pengujian hipotesis dilakukan dengan menggunakan analisis Uji beda (uji t) dua sampel independen (independent sample $t$ test) karena data tidak berasal dari kelas yang sama. Ketentuan yang berlaku adalah jika Asymp. Sig < 0.05, maka terdapat perbedaan yang nyata antara nilai hasil belajar pada kelas eksperimen yang menggunakan model pembelajaran kontekstual dengan kelas kontrol yang menggunakan model pembelajaran konvensional, sehingga $\mathrm{Ho}_{3}$ ditolak dan $\mathrm{Ha}_{3}$ diterima, begitu pula sebaliknya. Hasil uji tersebut dapat dilihat pada tabel 4.12 berikut;

Tabel 4.12

Hasil Uji beda Nilai Post test dan N-gain Antara Kelas Kontrol dan Kelas Eksperimen

\begin{tabular}{|c|l|c|c|l|}
\hline \multirow{2}{*}{ No } & \multicolumn{1}{|c|}{ Data } & Nilai Probabilitas & A & Keterangan \\
\cline { 3 - 5 } & $\begin{array}{l}\text { Post test Kelas Eksperimen dan } \\
\text { Kelas Kontrol }\end{array}$ & 0,000 & 0,05 & $\begin{array}{l}\text { Terdapat } \\
\text { perbedaan } \\
\text { signifikan }\end{array}$ \\
\hline 2 & $\begin{array}{l}\text { N-gain Pada Kelas Eksperimen dan } \\
\text { Kelas Kontrol }\end{array}$ & 0,003 & 0,05 & $\begin{array}{l}\text { Terdapat } \\
\text { perbedaan } \\
\text { signifikan }\end{array}$ \\
\hline
\end{tabular}

Sumber: Hasil Penelitian 2013 
Berdasarkan hasil pengujian hipotesis tersebut menunjukkan bahwa nilai probabilitas Post test Kelas Eksperimen dan Kelas Kontrol adalah 0.000, dan nilai probabilitas N-gain Pada Kelas Eksperimen dan Kelas Kontrol adalah 0,003. Keduanya berada pada nilai kurang dari nilai $\alpha 0,05$ sehingga $\mathrm{Ha}_{3}$ diterima artinya terdapat perbedaan yang signifikan antara hasil belajar pada kelas eksperimen yang menggunakan model pembelajaran kontekstual dengan hasil belajar pada kelas kontrol yang menggunakan model pembelajaran konvensional.

\section{b. Pembahasan}

Penentuan kelas sampel berdasarkan pada kesamaman karakteristik dari masingmasing kelas penelitian yaitu skor rata-rata nilai raport semester ganjil yang telah dilakukan sebelumnya dengan melihat nilai tertinggi, nilai terendah, dan rata-rata (mean) kemudian guru pengajar, metode, dan materi yang telah diajarkan (tabel 3.3). Berdasarkan indikator-indikator tersebut, maka dipilih kelas VII.F sebagai kelas eksperimen dan kelas VII.C sebagai kelas kontrol karena kedua kelas tersebut relatif homogen.

Kemudian merujuk pada hasil pengujian statistik terhadap skor pre test, kemampuan hasil belajar peserta didik kelas eksperimen dan kelas kontrol tidak berbeda secara signifikan. Maka dapat disimpulkan bahwa kemampuan awal kedua kelas penelitian adalah sama sebelum penerapan model pembelajaran. Sehingga persyaratan kondisi akademis dan metodologis antara kelas eksperimen dengan kelas kontrol telah terpenuhi untuk dijadikan sebagai subjek penelitian.

Berdasarkan hasil uji hipotesis, dapat dilihat bahwa terdapat perbedaan nilai hasil belajar pada kelas yang menggunakan pembelajaran kontekstual yang dilakukan di kelas eksperimen dengan kelas yang menggunakan pembelajaran konvensional yang dilakukan di kelas kontrol.

Hasil penelitian ini menguatkan bahwa pembelajaran kontekstual mampu membawa siswa mencapai tujuan pembelajaran (penguasaan materi pelajaran) yang berkenaan atau relevan bagi mereka dan bermakna dalam kehidupannya. Pembelajaran kontekstual sebagai alternatif strategi belajar memiliki landasan pada falsafah belajar yakni konstruktivisme. Konstruktivisme menekankan bahwa belajar tidak hanya sekedar menghafal, melainkan siswa mengkonstruksi pengetahuan dibenaknya sehingga dengan hal tersebut tercapai hasil belajar yang sesuai dengan tujuan pembelajaran (Ningrum, 2009:164).

Hasil belajar merupakan penguasaan terhadap berbagai pengetahuan, keterampilan dan sikap yang diperoleh setelah mengikuti proses belajar. Siswa belajar dengan baik dan mendapatkan hasil belajar yang sesuai tujuan pembelajaran karena dalam pembelajaran kontekstual selalu dikaitkan dengan apa yang telah diketahui dan dengan kegiatan atau peristiwa yang terjadi di sekelilingnya.

Berdasarkan temuan yang telah dipaparkan dalam hasil penelitian diketahui bahwa terdapat perbedaan antara tes awal (pre test) atau sebelum dilakukan pembelajaran dengan metode kontekstual dengan tes akhir (post test) setelah dilakukan pembelajaran dengan metode kontekstual. Hal tersebut dapat dilihat dari perbedaan nilai rata-rata antara pre test dengan post test sebesar nilai pre test 49,25 dan nilai post test sebesar 75,25.

Pada kelas kontrol dengan model pembelajaran konvensional proses tersebut juga terjadi akan tetapi tidak signifikan, hal ini dikarenakan peserta didik cenderung pasif yaitu mendengarkan, menerima, menyimpan, serta melakukan aktivitas yang sesuai dengan informasi yang diberikan oleh guru.

Pendekatan konvensional merupakan pendekatan pembelajaran yang berpusat pada guru (teacher centered) atau guru lebih mendominasi dalam kegiatan pembelajaran. Metode pembelajaran yang dilakukan berupa metode ceramah, pemberian tugas, dan tanya jawab (Wibawa dan Mukti, 1992:5). Proses pembelajaran konvensional dilakukan sebagai mana umumnya guru mengajarkan materi kepada peserta didiknya. Guru mentransfer ilmu 
pengetahuan kepada peserta didik, sedangkan peserta didik lebih banyak sebagai penerima, pada saat proses pembelajaran dan lebih banyak mendengarkan.

Akibatnya perolehan skor post test dan N-gain pada kedua kelas penelitian yang pada dasarnya merupakan skor kemajuan belajar setelah perlakuan menunjukan perbedaan yang signifikan antara skor post test dan $\mathrm{N}$-gain kelas ekperimen yang menggunakan model kontekstual dengan skor post test dan $\mathrm{N}$-gain kelas kontrol yang menggunakan pembelajaran konvensional. Dimana skor post test dan N-gain pada kelas eksperimen lebih tinggi daripada skor post test pada kelas kontrol.

Nilai rata-rata pre test antara kelas eksperimen dengan kelas kontrol memilik perbedaan, karena nilai di kelas eksperimen dengan menggunakan pendekatan kontekstual lebih tinggi dibandingkan di kelas kontrol yang menggunakan pendekatan konvensional. Di kelas kontrol nilai rata-rata pre test sebesar 47,50 sedangkan nilai di kelas eksperimen sebesar 49,25. Perubahan terjadi setelah dilakukan post test pada kedua kelas ini, nilai post test pada kelas eksperimen adalah sebesar 75,25 sedangkan pada kelas kontrol sebesar 62,75 perbedaan terjadi karena guru telah memberikan perlakuan yang berbeda pada masing-masing kelas. Kelas eksperimen menggunakan pendekatan kontekstual, sedangkan kelas kontrol diberikan pembelajaran secara konvensional atau melalui ceramah.

Ini menunjukkan bahwa metode pembelajaran kontekstual dapat memberikan pengaruh yang besar terhadap hasil belajar peserta didik, karena peserta didik dilatih untuk mencari permasalahan, mengumpulkan fakta atau data, memecahkan masalah tersebut kemudian mengembangkan dan menganalisis masalah tersebut untuk dicarikan solusinya.

Berdasarkan uraian diatas maka dapat disimpulkan bahwa peserta didik dengan pembelajaran model kontekstual pada kelas eksperimen, lebih baik daripada peserta didik pada kelas kontrol dengan metode konvensional. Sehingga dalam aspek hasil belajar, model kontekstual lebih unggul dibandingkan dengan model pembelajaran konvensional.

Namun apabila melihat dari nilai rata-rata pre test dan post test pada kelas eksperimen tersebut sebagaimana dapat dilihat pada tabel 4.2 dan 4.3 diperoleh hasil yang belum memuaskan. Nilai minimal post test 60 dan nilai maksimal post test 90 walaupun secara nilai rata-rata terjadi kenaikan dari nilai rata-rata pre test 49,25 menjadi 75,50 pada nilai post test. Artinya masih ada peserta didik yang memiliki nilai dibawah kriteria ketuntasan minimal (KKM) 70. Peneliti mengindikasikan hal tersebut disebabkan oleh beberapa faktor diantaranya, penelitian dilakukan mengacu pada alokasi waktu dalam KTSP SMP Negeri 4 Padalarang, dimana sub pokok bahasan kondisi geografis Indonesia disampaikan dalam satu kali pertemuan yaitu 80 menit, dengan rincian 10 menit pertama untuk pelaksanaan pre test, 60 menit untuk kegiatan pembelajaran, dan 10 menit terakhir untuk pelaksanaan post test. Terbatasnya waktu tersebut mengakibatkan kurang maksimalnya eksplorasi peserta didik terhadap konsep yang disampaikan. Sedangkan karakteristik model pembelajaran kontekstual menekankan pada 7 komponen yaitu : Konstruktivisme, inkuiri, bertanya, masyarakat belajar, model, refleksi, dan penilaian.

Model Pembelajaran kontekstual menuntut guru untuk bekerja lebih profesional, dan memerlukan kemauan serta motivasi yang bagus untuk keberhasilan proses pembelajaran peserta didik. Berdasarkan hasil tanya jawab dengan guru model setelah pembelajaran diketahui bahwa model pembelajaran kontekstual merupakan model yang baru bagi beliau sehingga butuh pembiasaan dalam pelaksanaanya. Kebiasaan peserta didik yang cenderung menjadi pembelajar pasif dapat menghambat ekplorasi konsep pada model kontekstual. Sehingga guru harus senantiasa memantau dan membimbing peserta didik dalam tahapantahapan pembelajaran kontekstual. 


\section{KESIMPULAN}

Berdasarkan hasil penelitian dan analisis data yang telah dilakukan, dapat ditarik kesimpulan secara umum bahwa penggunaan CTL pada materi Kondisi Geografis Indonesia kelas VII, berpengaruh terhadap hasil belajar. Hal ini dibuktikan dengan adanya perbedaan nilai tes awal dengan nilai tes akhir peserta didik yang signifikan antara peserta didik yang menggunakan pembelajaran CTL dengan peserta didik yang menggunakan pembelajaran konvensional.

Hasil analisis uji perbedaan skor nilai tes awal dan nilai tes akhir hasil belajar pada kelas eksperimen diperoleh nilai probabilitas $-11.099<$ nilai $\alpha 0,05$, sehingga $\mathrm{Ha}_{1}$ diterima artinya terdapat perbedaan tes awal dan nilai tes akhir dalam hasil belajar pada kelas eksperimen yang menggunakan model pembelajaran kontekstual.

Hasil analisis uji perbedaan pada kelas kontrol diperoleh nilai probabilitas $-6,773<$ nilai $\alpha 0,05$, sehingga $\mathrm{Ha}_{2}$ diterima, artinya terdapat perbedaan antara nilai tes awal dan nilai tes akhir dalam hasil belajar pada kelas kontrol yang menggunakan model pembelajaran konvensional. Dengan demikian dapat disimpulkan bahwa hasil belajar pada kelas kontrol menunjukan adanya perbedaan dari nilai tes awal dan nilai tes akhir, tetapi perbedaannya tidak sebesar pada kelas eksperimen.

Berdasarkan hasil pengujian uji beda nilai tes akhir dan N-gain antara Kelas Kontrol dan Kelas Eksperimen menunjukkan bahwa nilai probabilitas nilai tes akhir Kelas Eksperimen dan Kelas Kontrol adalah 0.000, dan nilai probabilitas N-gain Pada Kelas Eksperimen dan Kelas Kontrol adalah 0,003. Keduanya berada pada nilai kurang dari nilai $\alpha 0,05$ sehingga $\mathrm{Ha}_{3}$ diterima artinya terdapat perbedaan yang signifikan antara hasil belajar pada kelas eksperimen yang menggunakan model pembelajaran kontekstual dengan hasil belajar pada kelas kontrol yang menggunakan model pembelajaran konvensional.

\section{DAFTAR PUSTAKA}

Mahfudin, A. (2009). Profesionalisme Jabatan Guru Di Era Globalisasi. Bandung: Rizqi Press.

Ningrum, E. (2009). Kompetensi Profesional Guru dalam Konteks Strategi Pembelajaran. Bandung: Buana Nusantara.

Nursisto. (2001). Spektrum Pengalaman Lapangan dalam Dunia Pendidikan. Jakarta : Depdiknas.

Romli, O (2010). Penerapan Pembelajaran Kontekstual untuk Meningkatkan Prestasi Belajar Matematika: Studi Eksperimen pada Siswa MA Negeri Pandeglang Kabupaten Pandeglang. Tesis. Tidak diterbitkan.

Rusman, (2008), Manajemen Kurikulum Seri Manajemen Sekolah Bermutu, Bandung : UPI Press.

Sanjaya, W. (2007). Strategi Pembelajaran Berorientasi Standar Proses Pendidikan. Jakarta: Kencana Prenada Media.

Sudjana, N. (1989). Dasar-Dasar Proses Belajar Mengajar. Bandung: Sinar Baru Algensindo. Sukmadinata, N. S. (2013). Pengembangan Kurikulum (Teori dan Praktek). Bandung: Remaja Rosdakarya.

Sukmadinata, N. S. (2006). Metode Penelitian Pendidikan. Bandung: Remaja Rosdakarya

Sumaatmadja, N. (1997). Metodologi Pengajaran Geografi. Jakarta: Bumi Aksara.

Sumi'at. (2008). Upaya Pencapaian Kompetensi Dasar Membuat Dokumen Pengolah Angka

dengan Variasi Teks, Tabel, Grafik, Gambar dan Diagram Melalui Model

Penilaian Berbasis Portofolio (Penelitian Tindakan Kelas di Kelas XI.IPS.1 SMA

Negeri 1 Gebog Kabupaten Kudus). Tesis. Tidak diterbitkan.

Wibawa dan Mukti. (1992). Media Pendidikan. Jakarta: Depdiknas. 